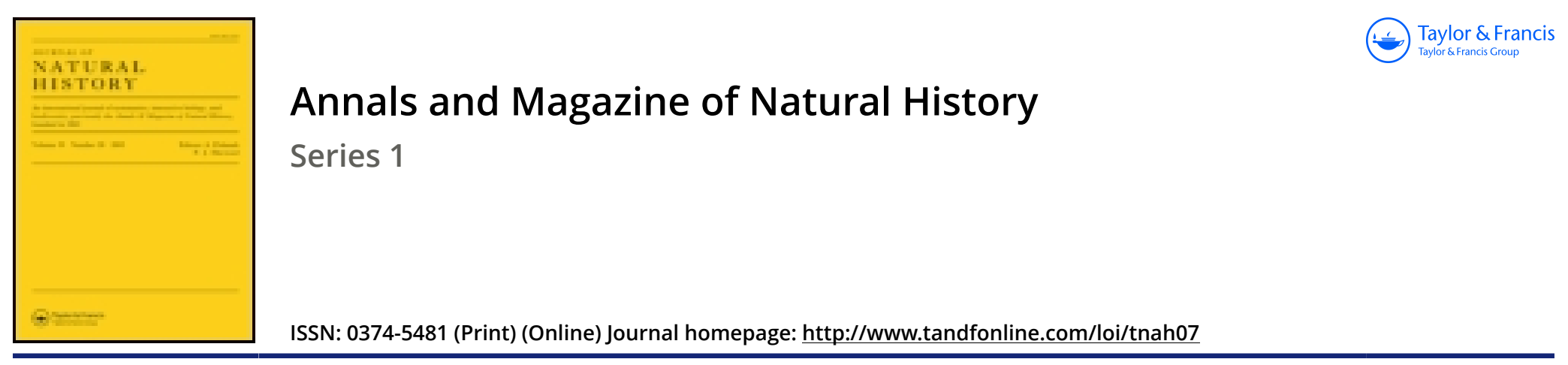

\title{
XLIII._Anatomical and physiological observations on some Zoophytes
}

\author{
John Reid M.D. F.R.C.P.E.
}

To cite this article: John Reid M.D. F.R.C.P.E. (1845) XLIII._Anatomical and physiological observations on some Zoophytes, Annals and Magazine of Natural History, 16:107, 385-400, DOI: $10.1080 / 037454809495965$

To link to this article: http://dx.doi.org/10.1080/037454809495965

册 Published online: 21 Dec 2009.

Submit your article to this journal $\sqsubset \pi$

Q View related articles $\sqsubset$

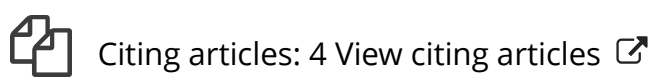


great in directing observers in a fruitful path and in exciting important researches, among which we may mention those of $\mathrm{Va}$ lentin, Vogt, Bergmann, Reichert, Bischoff, Barry, Lebert and Henle. In my turn I shall make known the result of the observations which I have made upon so disputed a subject-observations which during several years have been many times detailed in the course of instruction which I give in the College of France.

XLIII.-Anatomical and Physiological Observations on some Zoophytes. By JoH Reid, M.D., F.R.C.P.E., and Chandos Professor of Anatomy and Medicinc in the University of St. Andrews.

[With a Plate.]

Is the following observations upon the structures and actions of some of the Zoophytes obtained from the shore of the bay of St. Andrews, I have confined mysclf to those points which are either new, or which appeared deserving of additional illustration. In using the terms superior and inferior, upper and lower in reference to the relative position of different parts of the polypidom, in the descriptive parts of this paper, the polypidom is supposed to be in the erect position, so that these terms correspond to anterior and posterior when the polypidom is placed horizontally. In using the term anterior surface, I mean the surface on which the apertures of the polype-cells are placed, so that this corresponds to the upper surface when the polypidom is laid horizontally for examination.

Cellularia reptans. 'This polype grows in considerable abundance close upon low-water mark, on the exposed surface of a stratum of clay-slate and conglomerate, interposed among strata of sandstone belonging to the carboniferous series. Growing along with it, but in much smaller quantities, are Cellularia scruposa, Crisia chelata, C. eburnea, Pedicellina echinata, Vesicularia spinosa, Valkeria imbricata and Plumularia falcata, none of which have I hitherto found adhering to the surrounding strata of sandstoue.

The polypidom of this polype possesses some structures which as far as I am aware have not yet been described. At the external and upper angle of the cell, and posterior to the two spines attached to this angle (Pl. XII. fig. $1 a$, fig. $2 c, a, b$ ), three of these structures are found $*$. The uppermost of these is a hollow process (fig. $2 b$ ), the superior extremity of which is free, looks outwards and a little forwards, and has an aperture notched on the

* Part of this process is seen on looking at the anterior surface of the polypidom, as is represented in Plate XII. fig. $3 b$. 
lower and upper edges, but more deeply in the former than the latter. From this aperture a hair-like prolongation (fig. $2 d$ ), about the length of the cell, and slightly curved, projects. The interior of the process is filled with a fibrous contractile substance which moves this hair-like prolongation. Its movements occur at irregular, occasionally very short intervals, and it sweeps downwards over all the posterior surface of the polypidom within its reach. It then turns back upon its former track, ascending upwards until it reaches again the outcr edge of that part of the polypidom lying above the process to which it is attached; it now descends in the opposite direction over the outer part of the polypidom, and places itself along the outer edge of that portion of the polypidom lying below it. From this it re-ascends in the course just described. The extent of these movements is increased by the presence of the notches in the edges of the aperture through which the hair-like prolongation passes. These movements are perfectly independent of the polype and continue for days after its death. The upper and outer edge of the polype-cell is prolonged into a process (fig. 1 a, and fig. $2 c$ ) mucronated at its external and upper angle. This process is hollow and is filled with a pale fibrous contractile substance, which I have frequently seen become elongated and rise in the form of a short conical eminence above the upper edge of the process, and then after a while it contracted suddenly and retired within the process. This process was in some cells metamorphosed into a strong spine (fig. $1 b$ ), and in such cases three spines were attached to the external angle of the cell instead of two the normal number. It has an affinity with the tooth-like process of Cellularia scruposa, as both contain a similar contractile substance. Placed between the bases of the above two processes and overlapping the latter, is a rounded small cavity with a distinct circular aperture (Pl. XII. fig. $2 a$ ). In some cells all these three appendices are wanting; in others only one of the two former is present. The polype protrudes itself through a small aperture directed outwards and upwards, placed at the upper end of the cell and towards its outer edge, and immediately in front of the process bearing the hair-like prolongation (fig. $3 \mathrm{a}$ ). This aperture is crossed anteriorly by a pretty strong rim which forms the upper edge of the anterior surfacc of the cell, and posteriorly by the still stronger rim forming the upper edge of the posterior surface of the cell. Below this aperture there is a considerable portion of the anterior wall of the cell formed by a transparent membrane, and bounded by a thick edge, constituting the large oval opening in the anterior wall of the cell in dead or dried specimens. In the greater number of eells this space is crossed by bars of calcareous matter, growing from its inner margin by one stem which generally divides dichotomously into 
four, and these increasing in length reach its outer margin (fig. 3 a). These bars are hollow, are lined internally by a fine membrane, and almost entirely disappear when the polypidom is immersed in dilute muriatic acid. Neither these bars nor the three appendices to the cells above described, present themselves until the body of the cell and its containing polype have been fully formed. The spines attached to the cell are almost always four in number, - two to each superior angle of the cell,--are hollow, and the external two are longer and stronger than the in. ternal. The two former are of considerable thickness, and are generally as long, sometimes more than twice as long, as the cell.

The polype has from fourteen to sixteen ciliated tentacula, of a light orange-colour, rather more than three-fourths of the length of the cell. The animal when retracted within its cell is folded up as in Flustra foliacea. Fig. 5 is a representation of the polype when expanded, and fig. 4 represents its appearance as seen from the posterior surface when it withdraws and folds itself within the cell. In this polype the part marked $a$ in the figures had more of the appearances of an appendix of the stomach (b), or of a separate organ, than in some of the other ascidian polypes*. Its inner surface is so thickly covered with reddish brown granules, or more properly speaking, minute cells, that it is quite opake. Similar granules also adhered to the inner surface of the cesophagus $(d)$ and stomach, and sometimes in greater number to the former than the latter. The inner surface of the pharynx $(f)$, the cesophagus, the stomach, and a portion of the intestine (c) next the stomach are covered with cilia. A mass of darkcoloured egesta, apparently principally composed of the cells and granules thrown off from the inner surface of the digestive tube, is frequently observed about or above the middle of the intestine, and this part of the intestinal tube presents a dilatation frequently considerably larger than what is necessary to contain the inclosed mass. The polype in protruding itself first pushes out a short flexible tube attached to the inner margin of the aperture through which the tentacula pass. The muscles by which it withdraws itself within its cell are two in number, - one proceeding from the lower and outer part of the cell, and dividing into two bundles as it passes upwards, which are attached to the sides of the lower part of the pharynx; the other arising from the lower part of the cell and attached to the lower end of the appendix of the stomach (fig. $5 a$ ). The muscular bundles by which it protrudes itself cannot be distinctly traced from their proximity

* From the contractility of these parts the form is not uniform, and in some individuals we find the stomach less and the appendix larger than they are here represented. 
to the tentacula and intestine, but are seen passing downwards from the upper part of the cell along the sides of the tentacula to reach the gullet, and probably also the upper edge of the stomach. The flexible tube or operculum is retracted by two muscular bundles, one on each side, arising from the inner sides of and a little below the aperture of the polype-cell, and are inserted into the inner surface of the flexible tube. The young polype-cells, formed at the upper end of the branches, grow from the posterior surface of the polype-cells last formed a little below their upper margin. Their first appearance is that of a rough transverse line occupying the inner portion of that surface. Several specimens presented the bodies frequently termed opercula, but which we shall call ovary-capsules, placed as usual at the upper end of the polype-cells, and were here somewhat nearer their inner than their outer margins. The contents of these we shall describe in a subsequent part of this communication.

Cellularia scruposa. This polype is found, as I have already mentioned, in the same locality with C. reptans, and it is also thrown ashore from deep water, sometimes in considerable quantities and of more luxuriant growth, chiefly adhering to Flustra foliacea and F. truncata. A perpendicular hollow process springs from the upper and outer edge of the cell immediately above the already well-known tooth-like process, and adheres to the lower part of the outer edge of the cell immediately above (fig. $6 a$, and fig. $7 b$ ). The aperture of this process is pretty deeply notched before and behind, and its interior is filled with a contractile fibrous substance which moves a curved hair-like prolongation (fig. $7 b$ ) about the length of the cell, which sweeps at intervals over both the anterior and posterior surfaces of the polypidom within its reach. It rises up slowly over the anterior surface, makes a sudden jerk over the outer edge of the polypidom, and proceeds slowly downwards over the posterior surface as far as the notch in the aperture permits, and after remaining at rest for a longer or shorter time, it returns along the same course to the position from which it started. In this movement it performs a slight rotatory motion, so that its concavity is always directed towards the surface of the polypidom. This hair-like prolongation, in this as in Cellularia reptans, tapers gradually towards its free extremity, and is not rounded but flattened. In the C. reptans I never observed this hair-like prolongation cross the anterior surface of the polypidom, except when placed at the angle of the bifurcation of a branch. The use of these hair-like prolongations may probably be to keep the surface of the polypidom clear of substances which would otherwise adhere to it. Their motions are executed with more force than we should at first suspect. I have seen one of them in its course encounter the 
stalk of a Pedicellina echinata, and press it aside. The tooth-like process (fig. $7 c$ ) is hollow, has an aperture in its upper edge, and in several specimens I have observed it filled with a fibrous contractile substance which expands and rises upwards through the aperture, and after remaining stationary for a time it re-enters the process. It rises only a short distance above the aperture, and when expanded presents the appearance of the upper and outer angle of the containing process with the curve turned in the opposite direction. When expanding it moves from without inwards, gradually rising above the edge of the aperture, and it re-enters the process by a sudden jerk in the opposite direction. These movements of expansion and contraction commonly occur after long intervals, and it is in general only by watching a portion of the polypidom for a considerable time under the microscope that they can be detected. More rarely these movements occur in rapid succession. I can form no conjecture regarding the function of this curious contractile substance. At the root of the process bearing the hair-like prolongation there is a small rounded cavity with an aperture in its posterior wall, exactly like that described in the corresponding position in $C$. reptans (fig. 7 a). Each cell has four small hollow spines attached to its upper edge, two adhering to each angle. These spines are very considerably smaller than those in C. reptans, and in old specimens are generally broken off. The position of the apcrture in the cell through which the polype protrudes is similar to that in C. reptans, and is also provided with a short flexible tube, which acts as an operculum when the polype retires within its cell. Many specimens are provided with ovary-capsules placed as in $C$. reptans. The polype has generally twclve tentacula of a light orange-colour, and has in other respects a great resemblance to that in C.reptans, and is provided with the same muscular bundles for effecting its movements and closing the operculum.

Cellularia avicularis. I lately obtained a large and very perfect specimen of this polype. The shape of the polype-cell, as Dr. Johnston remarks, is similar to that in Flustra avicularis. The bird-process is also exactly alike in both. It can, however, be readily distinguished from the latter by all the branches being composed of two rows of semi-alternate cells, and each cell having only two conical spines directed upwards or in the line of the long axis of the cells, and a little outwards and forwards, and attached to the angles of the superior margin of the cell. In a small number of cells an additional small spine, making three in all, projected from the outer angle in the same direction as the normal one. On the other hand, almost all the cells in Flustra avicularis have four spines, which differ in appearance from those of Cellularia avicularis. This specimen when dried assumed 
only a very faint ash-colour, very different from the much deeper ash-colour in all the dried specimens of Flustra avicularis I have scen.

These two polypes ought certainly to be classed as two different species of the same genus, and not under two different genera. A new genus should perhaps be instituted for their reception, as their general character, and more especially the possession of those remarkable appendices, the bird-head processes, separate them from Acamarchis, Flustra and Cellularia, the genera to which they are most allied.

Pedicellina echinata. This polype is found in considerable quantities in front of the Castle of St. Andrew and near low-water mark, adhering to Cellularia reptans, to Sertularia, and to the surface of stones. It is more hardy than most of the other ascidian polypes, and can be kept alive at home for a long time. The number of tentacula varies from fourteen to twenty. In some specimens the stalk is nearly smooth, in others several spinous-looking processes project from it, and in others both stalk and body are covered with a long, fine and sparse down. In the young animal the body is relatively longer and narrower. The body in the older animal is very decidedly compressed from before backwards and elongated transversely, and is considerably narrower and more bulging at the edge in which the intestine lies' (fig. $8 d$ ) than at the edge next the gullet (fig. $8 a$ ). The upper part of the body is bounded by a slender rim to which the tentacula are attached. This rim slopes slightly from the narrow towards the broad end of the body. The tentacula at the extremity of the narrow end are shorter than the others, and all of them become considerably broader as they approach the rim. They are connected together at their lower third by a contractile membrane, partly composed of circular fibres. The body itself is not contractile. The inner surface of the edges of the tentacula and the inner surface of the rim are provided with strong cilia, and in the older animals the external surface of the tentacula is frequently covered with a layer of pretty large granules or cells. On examining the animal under the microscope whon placed in water containing a quantity of carmine, the movements of the currents of water produced by the cilia can be more distinctly observed. The two rows of cilia attached to each tentaculum do not produce currents in opposite directions, but both strike downwards and towards the mesial line of the tentaculum to which they are attached, and cause a current down the centre of its internal surface, by which the particles of carmine are carried downwards to the rim. When all the currents carried down the tentacula arrive at the rim, they are rapidly conveyed along its upper edge by the action of the cilia with which this portion of the inner surface is so abundantly 
provided, towards the mouth (fig. $8 a$ ). At this part all the currents converge, and thus produce an upward central current, by which the particles of carmine are carried outwards. None of the carmine, as far as I could observe, entered the csophagus. The particles of carmine sometimes collected in considerable masses around the mouth before they were floated outwards. As the termination of the intestine opens near to the mouth, and at a point within the influence of this outward central current, the egesta when voided are rapidly carried away. It would thus appear that when substances not fitted for the nourishment of the animal are conveyed towards the mouth, the walls of this aperture are endowed with a specific property of irritability by which they are thrown into contraction and prevent its entrance. Such substances on the other hand as are capable of nourishing the animal do not act as excitants to this property of contractility, and they may be carried inwards. The possession of such a property is probably necessary for the existence of the animal. In this animal, as is well-known, the whole digestive tube and the ciliary motions on its inner surface can be distinctly seen through the transparent body. The walls of the stomach (fig. $8 b$ ) and the first portion of the intestine (duodenum ?) (fig. $8 \mathrm{c}$ ) are very much thicker than the rest of the digestive tube, and were never observed to contract; and this last circumstance, viz. the non-contractility of these parts of the digestive tube, does not exist, as far as I am aware, in any other ascidian polype. A slight contractile movement was observed in a few cases at the upper part of the gullet. The last part of the intestine (fig. $8 d$ ), which is not provided with cilia, contracts and expels the egesta which have previously accumulated there, frequently in considerable quantity. Brownish masses, apparently chiefly composed of the granules and cells which so abundantly line the inner surface of the stomach, are frequently seen in rapid rotatory motion in the stomach and duodenum.

The life of the body is of shorter duration than that of the stalk, and $\mathrm{I}$ have observed in several specimens the body fade and fall off, and a new one reproduced in its place. A few days before this takes place, the tentacula are permanently bent inwards and the membrane surrounding their lower part remains contracted, so as to completely, or nearly completely, cover the upper surface of the body, presenting in fact the appearance which the animal temporarily assumes when disturbed. The body then becomes more opake and at last falls off. After this the stalk retains its property of alternately contracting and relaxing its different surfaces at intervals, upon which its movements depend. After the lapse of a few days the top of the stalk enlarges, and a minute head presents itself in which the different parts of the 
body are developed. In the beginning of October I procured several specimens in which a large mass of cells (ova) was placed in the space between the gullet, intestine and upper edge of the stomach (fig. $8 h$ ), extending downwards to the entrance of the gullet into the stomach, and depressing the stomach and forcing it considerably downwards. In two of these this mass of cells projected into the interior of the gullet near its lower part, and exceedingly minute ciliated ova were seen escaping from the upper part of the cellular mass, and several were also seen swimming in the interior of the gullet and stomach. Portions of this mass of cells were after a time extruded outwards, and were composed of the ciliated ova, and of very minute nucleated cells connected together by a structureless substance. Many of these ova formed a single cell, broader at one end than at the other, with a circle of cilia. longer than the cell placed around the margin of the broad end (fig. $9 a$ ), while others presented one, two or more very minute cells attached to its lower or narrow extremity (fig. $9 b \& c$ ). The nucleated cells consisted of a cell-membrane with two or more nuclei, and appeared to be undeveloped ova. The ciliated ova swam actively about, sometimes bending all their cilia in the same direction, forming a curved bundle and striking in the same line for some time together, at other times spreading their cilia and moving them in different directions. These ova are so minute as to require very high magnifying powers for their examination. It would thus appear that this polype, supposing all the individual animals whose stalks are attached to the same creeping stem to form one aggregate animal, extends and prolongs the life of the individuals composing it in two ways ; viz. by renewal of the individual bodies after they have dropt off, and by offsets of new individuals from the creeping stem; and that it reproduces and extends the species, or forms new aggregate animals, by the formation of ciliated cells. I have never been able to detect any circulation of nutritious juices in the stalk, though examined under the most favourable circumstances.

Crisia chelata. This polype when extruded affords a good view of the membrane connecting the outer surface of the pharynx and rectum together (fig. 10 a). It would be more correct to say, connecting the supporting part of the tentacula and rectum together, for the pharynx, as in the other ascidian polypes, lies loose, and can be seen contracting, within this supporting part. It protrudes itself through a small opening at the upper margin of the cell, and the large opening seen in the dead specimen on the anterior surface of the cell, is in the living specimen covered in by a membrane. The polype has from ten to twelve ciliated tentacula about half the length of the cell. The dilatation of the digestive tube (stomach) at the termination of 
the gullet and commencement of the intestine is smaller, and that part marked $a$ in fig. 4 and 5 is relatively larger in this polype than in Cellularia reptans and $C$. scruposa, and has less the appearance of an appendix of the stomach*. Its inner surface, however, is covcred with a greater number of brownish granules than any other portion of the intestinal tube.

Campanularia dumosa. I have procured some live specimens of this polype thrown ashore after a storm attached to Flustra foliaceu. The polypes and pith of the stalk are of a yollow colour. The polypes were sluggish, had twelve short tentacula not ciliated, and presented all the characters of the Zoophyta hydroida. Dr. Johnston writes me that he has also some time ago procured live specimens, so that he must be now aware that this polype cannot be a Comularia as he once supposed (British Zoophytes, p. 192, 1838), and that the character's of the polypidon separate it from the genus Campanularia.

Alcyonidium parasiticum. Abundance of this polype is occasionally thrown ashore chiefly adhering to Sertularia argentea. I have procured several specimens alive, and have satisfied myself that it consists of cells composed of animal and calcareous matter, and that the polype resembles the ascidian polypes in every respect. Mr. Hassall (Annals of Natural History, vol. vii. p. 370) first satisfactorily ascertained the true nature of this polype. On placing a portion of the polypidom under the microscope, and then bringing a quantity of dilute muriatic acid in contact with it, innumerable bubbles of gas are seen rising from all parts of its surface. On immersing another portion in aqua potassa so as to destroy the animal matter, it lost its dirty brown colour, and the form and arrangement of the cells were then distinctly observed. Figure 11 is a magnified view of a few of the cells in the portion of the polypidom thus treated. Each cell is provided with a flexible tube attached to its margin, which the polype extrudes before it emerges from the interior of the cell, and retracts when it re-enters, thus serving the purpose of an operculum. The first portion of this operculum extruded, forms a small conical eminence with the apex truncated. When the polype withdraws itself within its cell, it frequently does not retract this portion of the operculum, so that the surface of the polypidom occasionally presents under the microscope a papillose appearance. The next stage in the protrusion of the polype is the clongation of this conical eminence by the eversion through it of a second portion, surmounted by pretty long setæ. The tenta-

* As has already beeu stated, I have observed individual polypes both in Cellularic reptans and scruposa, but more especially the latter, where the difference between the size of the stomach and appendix was less marked than in figs. 4 and 5 . 
cula, by the upward motion of which the eversion of this flexible tube is effceted, are now seen lying within it. The third stage in the protrusion of the polype is the passage of the tentacula and pharynx through the upper aperture of the Hexible tube. The greater part of this tube appears to be composed of setre connected together by a membrane. The polype has fifteen or sixteen tentacula. By breaking up a number of the cells I procured two of the polypes nearly entire, and the stomach and its appendix had nearly the same relative size as in Crisia chelata. Several bodies, each composed of reddish brown nucleated cells inclosed in a membrane (ova), were seen among the brokendown cells.

Flustra avicularis. This polype is thrown ashore in great quantitics after storms, chiefly adhering to the roots of Flustra foliacea and $F$. truncata. The cells have almost always four hollow spines, adhering to the upper margin of the cell, two to each angle. The two superior spines are pretty long and project upwards and outwards, and the two inferior, which are placed close to the two superior at their origin, are considerably shorter and less thick, and project generally inwards, forwards and a little downwards. In a few cells I have seen five spines attached to the superior margin, three of these adhering to the outer angle. The bird-head processes attached to the outer edges of the branches of the polypidom are generally very considerably larger than those nearer their centres. Each bird-head process may be described as being composed of a body (fig. $12 f$ ), of a hingeprocess (fig. $12 e$ ), and of a pedicle (fig. $12 \mathrm{~b}$ ). By the pedicle it is attached to the interior of a round hollow process projecting slightly from the anterior surface of the polypidom (fig. $12 \mathrm{a}$ ). The body of the bird-head process* is very convex along the lower edge, and it is elongated from below upwards and somewhat flattened transversely. It is divided by an oblique ridge on its intcrior surface into two chambers (fig. $12 d$ ), which communicate frecly at the superior and middle parts at least. The hinge-process is articulated to the superior or concave surface of the body by a hinge-joint, along the line of the superior termination of the internal ridge which divides the body into two parts. The edges of the concave surface are thickened at this part, and present a slight depression on each, for receiving the two articular processes of the hinge-process. The body of the bird-head process is hollow, and its concave surface presents thrce apertures; the largest of these is the uppermost, and is separated from the middle by a bar stretched across between the articular cavities

* In describing this moveable bird-head process, I have supposed the polypidom to be erect, and the concave surface of this process to be looking upwards in tive direction of the long axis of the cells. 
for receiving the hinge-process; and the smallest is placed at the lower end, and affords a passage to the posterior part of the pedicle into the interior of the body. The hinge-process is concave on its upper surface, and terminates below in a curved point. Its superior wall forming its concave surface is deficient in twothirds of its length at the upper part or that next the articulation, and its inferior or convex wall is very thin over the same extent. It is hollow, and communicates with the body through the upper and middle apertures seen in its concave or upper surface. Its upper or articulating end is bounded by a thickened portion or bar passing between the edges of the superior surface, and a similar bar passing between the edges of the inferior or convex surface. The articulating processes are placed upon the superior of these bars, at its junction with the edges of the superior surface. I have described, with what may appear very unnecessary minuteness, the skeleton of these bird-head processes, because it would be im. possible to understand their movements without a previous knowledge of the different parts described. The lateral portions of the lower chamber of the body are occupied by two radiating muscles, presenting somewhat of the appearance of the temporal muscle in the human species; which converge at the articulating or upper edge of the hinge-process, and terminating in a denser, thicker and narrower structure, which I shall call tendons, are attached to and move this process (fig. $12 \mathrm{c}$ ). One of these muscles, which is the stronger, terminates in a tendon which runs above the transverse bar which separates the upper from the middle aperture in the concave surface, and running down the centre of the hingeprocess is inserted into the inner surface of its inferior or convex wall a little above its apex or free extremity. When this muscle contracts, the hinge-process is tilted up. The other muscular bundle, which is strongest at the upper and lower edges, terminates in a tendon which passes beneath the bar, and is inserted into the hinge-process close to and a little above the tendon of the other muscle. When this muscle contracts, the hinge-process, if elevated, is drawn down. 'The first-described rnuscle is the elevator, the second is the depressor muscle of the hinge-process. The movements of the hinge-process are in general slight, but I have frequently observed it to be tilted up with considerable force, and closely applied over the superior surface of the anterior chamber, so that its concave, which was before its superior, became its inferior surface, and its convex became its superior surface. In this state it may remain for hours, and affords an excellent opportunity for observing the arrangement of the fibres of the two muscles, especially that of the elevator, as its lower fibres run more directly upwards, and its tendon is raised and separated from that of the depressor muscle. In dead specimens 
the hinge-process is not unfrequently found in the position into which it is brought by the action of the elevator musele. These muscular fibres present no transverse strix, can contract and relax with rapidity, and become shorter and thicker during their contraction. The movements of the body upon the polypidom are effected by the pedicle, and are as follows:- Suppose it to be attached to one of the edges of the polypidom, and the concave or' upper surface to be looking upwards in the line of the long. axes of the cells, it can turn slowly outwards over the edge of the polypidom until its concave surface looks directly outerward, and it then returns to its former place: it may also turn inwards until the concave surface looks across the cells. This movement being suspended, it exhibits at intervals a nodding motion, the concare and convex surfaces being alternately depressed towards the anterior surface of the polypidom. When the concave surface is carried downwards, the hinge-process is slightly separated from the body; but when the convex surface is depressed, it is again approximated. These last movements of the hinge-process are probably in a great measure mechanical, and occasioned by it rabbing over the surface of the polypidom during the downward motion of the concave surface. The pedielc consists of two parts : a posterior and dense portion which is attached to the internal surface of the inferior edge of the process of the polypidom to which it is fixed, and passes inwards through the inferior aperture in the concave surface of the body to be inserted into the lower part of the internal surfiace of the convex surface of the body; and an anterior portion, more translucent and less dense, which is prolonged downwards into the process, and forwards to the middle aperture in the concave surface of the body and the attachcd end of the hinge-process. In the nodding movements when the convex surface is moved downwards, the posterior edge of the pedicle contracts and becomes bent so as to form an acute angle; and it relaxes while the concave surface of the body is moved downwards, resembling the contractile movements of the stalks in Pedicellina echinata. I have never had an opportunity of observing the changes in the pedicle during the other movements of the body under a high magnifying power, as this can only be done under certain conditions not easily to be obtained. The anterior portion of the pedicle has more of the appearance of a membranous than a contractile structure, and contains several small nucleated cells. $\quad \Lambda$ similar structure is found in the upper chamber of the body, and is prolonged through the upper aperture in the concave surface into the hinge-process. I have not been successful in observing contractile movements in this structure, if it really possesses this function, and I believe that it is more connected with the 
nutrition of these bird-head processes than with their movements. It would be very interesting to ascertain the functions of these complex appendies to the polypidom. Their movements are quite independent of the polypes, and continue for days after these are dead. The hollow processes of the polypidom, at least those next the outer edges, to which these bird-head processes are attached, spring from the upper surface of canals which communicate with the interior of the spines, the ovary-capsules, and also by lateral apertures with the interior of the cells next them. Can these organs assist in circulating water along these canals?

The body of the polype is very small when compared with the length of the cell, so that when it enters the cell, the gullet and intestine are not folded upon themselves as in Cellularia reptans and so many other of the ascidian polypes, but are simply thrown into a curve. It has fifteen or sixtcen ciliated tentacula considerably longer than the body : the cilia are short, thick and numerous. In this polype, as in the Crisia chelata and Alcyonidium parasiticum, there is not so marked a division between the stomach and the part which has been termed the appendix, as in Cellularia reptans and $C$. seruposa. Brownish granules and minute cells are observed on the inner surface of the stomach, the gullet and commencement of intestine. Ciliary movements are distinctly seen in this as in the other ascidian polypes examined on the inner surface of the pharynx, gullet, stomach and first portion of intestine. In some specimens the polypes were very active, darting back into their cells when disturbed, and immediately after again protruding themselves. When left undisturbed, they at short intervals partially withdrew into their cells, and immediately after again emerged and spread out their tentacula. The movements of the cilia attached to the tentacula appear to be in this, as in other ascidian polypes, under the control of the animal. They remain quiescent when the tentacula are withdrawn within the cell; and even when extruded their movements are occasionally for a time suspended. There can be no doubt that they can act also involuntarily, for they may be scen in full action upon detached portions of the tentacula. Very extensive contractile movements were very frequently observed in the pharynx, gullet and stomach. The arrangement of the muscles, by the action of which the polype protrudes and withdraws itself within the cell, appears, as far as I could trace them, similar to those in Cellularia reptans and scruposa. The greater number of specimens were provided with ovary-capsules, placed upon the thickened superior margin of the cells. In some specimens pro-

* This is a mere conjecture thrown out for future investigation. 
cured about the middle of October, these ovary-capsules were more or less filled with opake bodies (ovaries) of a slightly yellowish colour. Each of thesc bodies was composed of small nucleated cells inclosed in a membranc. The external surface of this membrane was in many of them provided with cilia in motion, causing some of them to perform a rapid rotatory motion within the ovary-capsules. These ova in the first stage of their growth adhere to the upper end of the lining membrane of the capsule. This lining membrane stretches across the aperture in the capsule, and also sends a reflection across the cell immediately below the ovum so as to inclose it in a kind of sac, leaving however, in the young ovum, a space between them. In the more advanced ova, this membranous partition was much thickened, especially at the central part, forming a considerable projection in the direction of the aperture in the capsule, and contained a number of nucleated cells. When the ovum enlarges so as to fill the interior of the capsule, it pushes this membranous partition before it. This membrane was observed in a few instances where the ova were fully formed to contract and relax at intervals, and in this way it may assist in the escape of the ovum. On detaching some of the ovary-capsules with the riew of examining their contents under a high power, one of the ova was seen partially extruded from the aperture in the capsule. It was divided by a deep fissure into two uncqual parts, the largest of which was nearly entirely outside the capsule (fig. $13 \mathrm{a}$ ). The extremity of the largest portion (fig. $13 \mathrm{c}$ ) was distinctly prolonged, more translucent than the rest of the ovum, and presented along its free edge a row of hairs resembling cilia, which, however, remained quite motionless, while along the whole of the rest of the external surface of both portions, except upon the edges of the fissure, cilia were in such vigorous action that it was impossible to distinguish them individually, and they produced the appearance of the rim of a wheel in very rapid rotation. After the lapse of an hour the fissure had cxtended through the whole body of the ovum, and the larger portion (fig. $13 b$ ) bcing set free, swam about very actively in the water; but all this time the hairs attached to the prolonged anterior portion remained motionless. The smaller portion contimucd in the capsule, and performed very rapid rotatory movements. This was the only ovum I observed in the act of escaping from the interior of the capsule, but I had an opportunity of watching three other bodies exactly similar to the larger portion of the ovum already described, when examining other portions of the same polypidom. One of these had become fixed, by the hairs attached to the anterior extremity, to a minute portion of sea-necd, and the cilia were in active motion. When examined ten hours after, 
the cilia were acting very languidly. I saw another while swimming about become entangled by its cilia to the setre projecting from the body of a small annelide. During the movements of the annelide, the hairs on the prolonged anterior extremity came in contact with some small fragments of sea-weed, and the annelide after some struggles detached itself from the ovum, which continued to adhere to the sea-weed. In all of these I never observed the least movement of the hairs attached to the anterior extremity. I was not able to ascertain that the smaller portion of the ovum left in the capsule underwent any change, as I presume it does, before it escaped from its interior. Several bodies, having one portion of their surface ragged and devoid of cilia, and in every other respect resembling the smaller portion of the ovum, and also other bodies exactly similar to the entire ovum, were observed swimming about; but as in all these cases the portions of the polypidom had been injured immediately before, and some of the ovary-capsules broken, it was presumed that these had been mechanically displaced from the capsules. The larger portions of the ova were, like the entire ova, composed of minute nucleated cells, and did not, as far as I could discover, possess any internal cavity.

In several specimens of Cellularia reptans and C. scruposa, and one specimen of $C$. avicularis procured at the same time, the ovary-capsules were filled with ova; in the two former of a deep orange colour, composed of nucleated cells, having the same number and arrangement of membranes and provided with cilia as in Flustra avicularis. Some of these ova were in rapid rotatory motion; others, as in Flustra avicularis, were motionless, though the cilia were acting, being kept quiescent by the more close apposition of the inclosing membrane. I did not succeed in observing the escape of any of these ova from their eapsules. In many of the polype-cells of all of the above-mentioned polypes, dark red bodies composed of nucleated cells inclosed in a membrane were present. These nucleated cells are generally considerably larger than those entering into the formation of the ova in the ovary-capsules. The greater number of polypecells contained one only of these bodies, and it was connected to the inner surface of the cell by a membrane having a number of detached nucleated cells of a light colour adhering to it. These bodies occupied different positions between the bottom and aperture of the cells, but in none were distinct ciliary motions observed. These bodies are also probably ova, and it is possible that more extended observations may enable us to detect cilia on their surface at a more advanced stage of dcvelopment, though none in the present case were seen even on those lying at the aperture of the polype-cells. I have satisfied my- 
self that in the polypes mentioned above, the inner surfaces of the polypc-cells, of the appendices of those processes described in the Celluklaria reptans. and scruposa, of the bird-head processes, of the spines, and of the canals running along the lateral surfaces of the polypidom in Flustra avicularis, are all lined by a fine membranc. This membranc in old specimens, and when the polypes are dead, often presents numerous and pretty large cells, gonerally of a pale colour, at other times having a slightly ycllowish or brownish tinge, adhering to its free surfaces. In one specimen these cells had accumulated in such quantities within some of the spines in Flustra avicularis, as to produce considerable bulgings and excrescences. The growth and nutrition of the hard parts of the polypidom must be chiefly due to this membrane.

\section{EXPLANATION OF PLATE XII.}

Fig. 1. Magnified view of the posterior portion of the upper end of a branch of the polypidom in Cellularia reptans. It is slightly elevated on the lcft side, so that the polype-cells of that side are better seen than on the other.

Fig. 2. Three appendices to the cells in Cellularia reptans.

Fig. 3. Magnified view of four polype-cells of Cellularia replans seen on the anterior surface.

Fig. 4. Magnified view of polype in Cellularia reptuns when folded up in its cell.

Fig. 5. Magnified view of this polype when expanded.

Fig. 6. Magnified view of the anterior surface of the upper part of one of the branches of the polypidom in Cellularia scruposa. The polypecells are in this drawing also more distinctly seen on one side than on the other.

$\mathrm{Fig} .7$. Magnified view of three appendices to the polype-cell in Cellularia scrupos $a ; b, b, b i s$, views of the process bearing the hair-like prolongation in two different positions.

Fig. 8. Greatly magnified view of head and lipper part of stalk in Pedicellina echinata.

Fig. 9. Greatly magnified view of the ciliated ova of Pedicellina echinata. Fig. 10. Magnified view of polype in Crisia chelata.

Fig. 11. Magnified view of polype-cells in Alcyonidium parasiticum.

Fig. 12. Magnified view of bird-head process in Flustra avicularis.

Fig. 13. Magnified view of ova in Flustra avicularis.

XLIV.-Observations on the Spongiadæ, with descriptions of some new genera. By J. S. BowerbanK, F.R.S., L.S. \&e.

[With two Plates.]

The microscopical examination of several hundred species of the Spongiada has led me to believe it possible that a series of characters may be obtained from the anatomical structure of the skeleton, which, from their constancy and striking peculiarities, will enable us to establish genera, based upon more certain cha- 